\title{
Woke Culture Syndrome: \\ Is Research in Management Under Threat?
}

\author{
Professor Gilles Paché \\ CERGAM, Aix-Marseille University \\ IUT-TC Aix \\ 413 Avenue Gaston Berger \\ 13625 Aix-en-Provence Cedex (France) \\ E-mail: gilles.pache@univ-amu.fr
}

Received: Dec. 13, 2021 Accepted: Feb. 14, $2022 \quad$ Published: April 1, 2022

doi:10.5296/jmr.v14i1.19323 URL: https://doi.org/10.5296/jmr.v14i1.19323

\begin{abstract}
Woke culture is spreading rapidly on North American campuses, and it is beginning to be discussed in Europe, particularly in France, within various universities. The advocates of wokism want to make people aware of the relationships of domination and social injustice induced by the political system in place. For the moment, research in management seems to escape the evils of woke culture syndrome in its most extreme manifestations (censorship, cancel culture, online harassment, etc.). The scope of this research note is to underline that the threat is credible, taking the case of research in logistics management. From a methodological point of view, an analysis of works using logistics to better understand societal phenomena allows us to identify "sensitive" topics, addressed by previous academic contributions, that may be difficult to address in the coming years under the pressure of wokism. The findings highlight two results concerning logistics: a framework for reading historical phenomena differently; and a framework for better understanding the sex industry. The main limitation is that the research note focuses only on four examples; from this point of view, perspectives are opened for a systematic analysis of the risks that wokism presents for research in management.
\end{abstract}

Keywords: Domination, Europe, logistics, research in management, social injustice, United States, university, woke culture, wokism. 


\section{Introduction}

Wokism has been spreading like wildfire on many American campuses for several years, leading to the exclusion of some of the most brilliant professors; the case of Evergreen State College is an excellent illustration (Hartocollis, 2017; Wagener, 2021). It is now a concern for many research communities, and it would be foolish to think that the management research community is immune to its excesses. Referring to a woke culture, wokism refers in fact to a set of streams of thought which, under progressive presuppositions, fight for an ideological conception of what is considered a "just cause", notably through the defense of various human groups considered as oppressed and/or humiliated. It is not so much such defense that is problematic, but rather the way in which the debate is often "anesthetized", for fear of addressing this or that sensitive topic head on, in a "detached" manner. This leads some researchers not to deal with important issues, or to deal with them in a biased way, in order to avoid controversies that could harm their academic careers. This will be even more true when the researcher is convinced that other people are in charge of their lives, in reference to the concept of "locus of control" (Lefcourt, 1991; Galvin et al., 2018).

Wokism is particularly relevant to the social sciences, especially in the context of studies on colonialism or feminism. For example, work is being done in departments of history to question the background of famous past politicians or thinkers and to highlight their racist stance, even if it was brief and only a youthful mistake. More recently, however, woke culture syndrome seems to be spreading to departments of political science (Rom \& Mitchell, 2021), or even department of science and technology, attacking the work of renowned researchers. For example, the New York Times reports that Canadian researchers working on ancient-DNA are now taking the precaution of seeking the advice of actual descendants of the skulls they are studying in order to confirm their findings (Imbler, 2021). The reason for this is that the researchers had shocked Aboriginal peoples by using terms such as "skull \#14", considered culturally insensitive, to refer to a tribal ancestor. More generally, it is the governance of universities that is called into question, particularly when it appears that the trustee board does not include minorities in a significant way (Bjorklund \& Green, 2012).

Research in management does not seem to be concerned by the abuses of wokism, even if managerial practices such as corporate social initiatives are beginning to be attacked (Warren, 2022). Certainly, the woke culture syndrome is gradually spreading to the business world, as the case of Antonio Garcia Martinez can testify. Recruited in April 2021 by Apple to take charge of its advertising platform, this former top manager of Facebook was fired one month after a petition was signed by more than 2,000 Apple employees protesting against his hiring. The reason for the discontent was related to the publication of an autobiographical book by Antonio Garcia Martinez in 2016, parts of which were considered sexist or racist (Garcia Martinez, 2016). On the other hand, management researchers seem to be protected from the attacks of wokism for the time being. It is not certain that this situation of quietude will last long, and it is possible to imagine that contributions in human resource will quickly be attacked on certain sexist dimensions, for example when it comes to questioning the sacrifice that women are ready to make for the success of their company (Guillaume \& Pochic, 2019). This research note highlights that even work in logistics management is threatened by wokism, even 
though its dimension is ultimately very operational, with the traditional objective to add value through the product flow operations (Antoniolli \& Camello Lima, 2014).

\section{General framework}

According to the Merriam-Webster dictionary, the word "woke" comes from American slang and refers to a heightened awareness of important societal issues, particularly social justice (Caldera, 2018). It was in February 2008 that the U.S. singer Erykah Badu, with her track "Master Teacher", brought the mantra "I stay woke" into popular culture, especially among millennials. As a system of thought, wokism refers to being politically or culturally aware or knowledgeable, especially about issues related to marginalized communities. In a way, a person adopting wokism has -finally- "woken up" to the oppression of a minority (Rhodes, 2022). Wokism thus encompasses several social struggles around issues of equality, justice, and the defense of minorities: the fight against racism, the fight against sexism, or the fight for LGBTQIA+ rights. The result is a multitude of modes of action, sometimes questionable such as censorship, re-evaluation of the past with today's point of view ("cancel culture") (see Fig. 1), and online harassment campaigns. Wokism combines ideas of intersectionality, which holds that certain discriminations add up, non-mixing for gatherings of people experiencing discrimination, and denunciation of systems of oppression and prejudice related to gender and sexual orientation (Valentin, 2021).

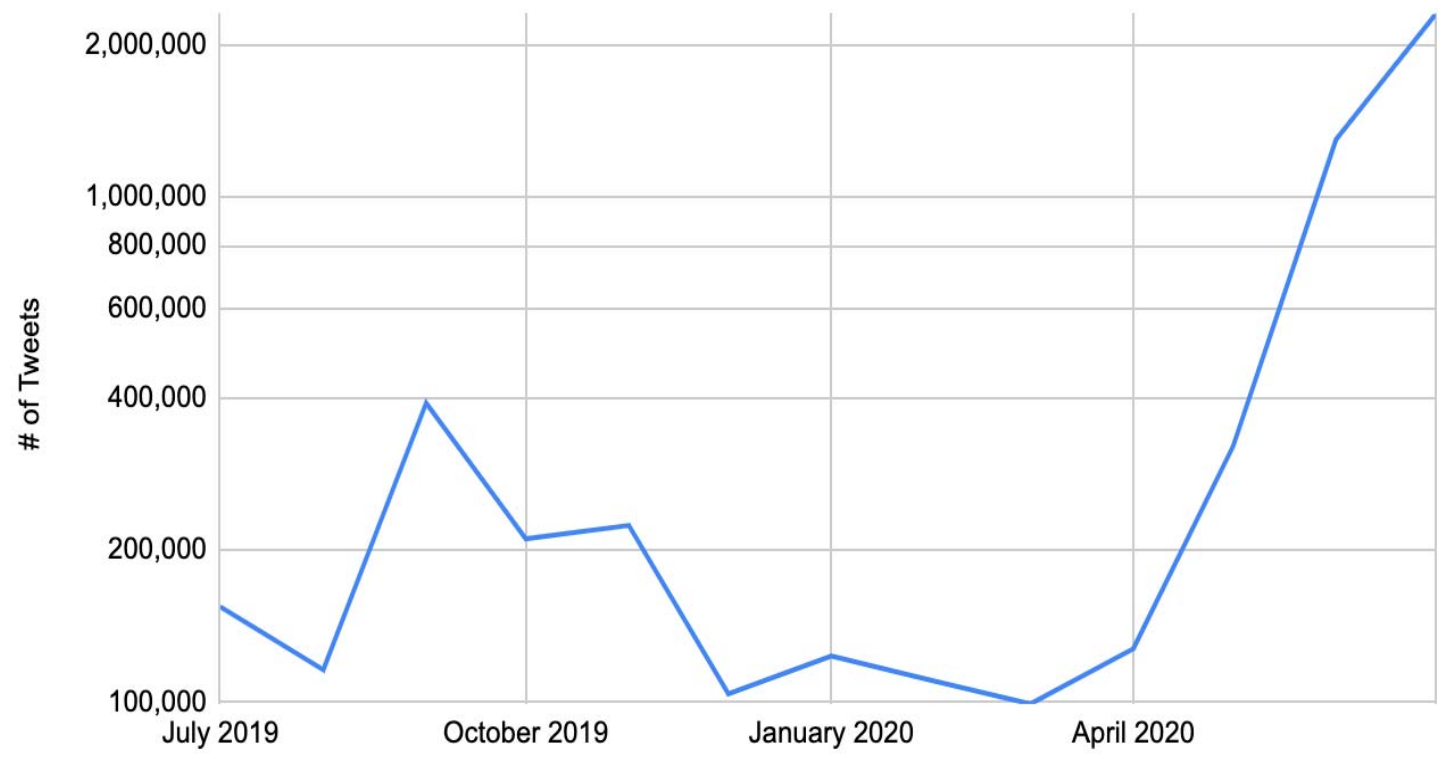

Note: Volume of Tweets using either the phrase "cancel culture" or the hashtag \#CancelCulture.

Fig. 1. Number of Tweets mentioning "cancel culture": a worrying trend Source: ListenFirst (2020).

Peter Boghossian highlights the excesses of wokism at his university in the United States in an interview with Le Figaro Etudiant (Conruyt, 2021). Recruited as professor to teach philosophy of ethics, he notes that more and more students refuse to discuss with people who do not share their values, while some professors are criticized for studying French and German philosophers because they are white and European. He adds that questioning the relevance of safe spaces or certain concepts such as "racial consciousness" earns the researcher who ventures into it to a 
sharp criticism. Even more seriously, the university's president goes so far as to publicly state that the priority research topic for his institution is social, diversity and inclusion. To underline the absurdity of wokism, Peter Boghossian and his two colleagues James A. Lindsay and Helen Pluckrose have written a famous hoax article under the identity of a fake "Helen Wilson", on a totally wacky theme and which was finally accepted by one of the best journals on gender studies, before being retracted by the editorial board (Wilson, 2018). This will earn Peter Boghossian his dismissal by the trustee board of his university.

In the end, wokism is a kind of catch-all concept that can be applied in almost any country. To do this, it is enough to identify a major form of oppression in a specific region or nation, to make it known that every individual should be more sensitive to it, and to propose a theorization that challenges any possibility of an alternative, or simply more nuanced, reading of the social phenomenon studied. Even more seriously, one can imagine that researchers studying this phenomenon in a scientific manner, using a rigorous methodological approach, could be accused of indirectly defending the oppressor. Some observers, however, are nuanced in speaking of a North American abuse that has little to do with European culture, where argued debate remains dominant in the academic world. As Fig. 2 shows, the words "racist" and "racism" are increasingly used by the four major daily newspapers in the United States (Goldberg, 2020). This is undoubtedly a direct result of the "Black Lives Matter" movement, and the \#StayWoke hashtag that quickly spread on North American social networks, but which rather spared Europe.

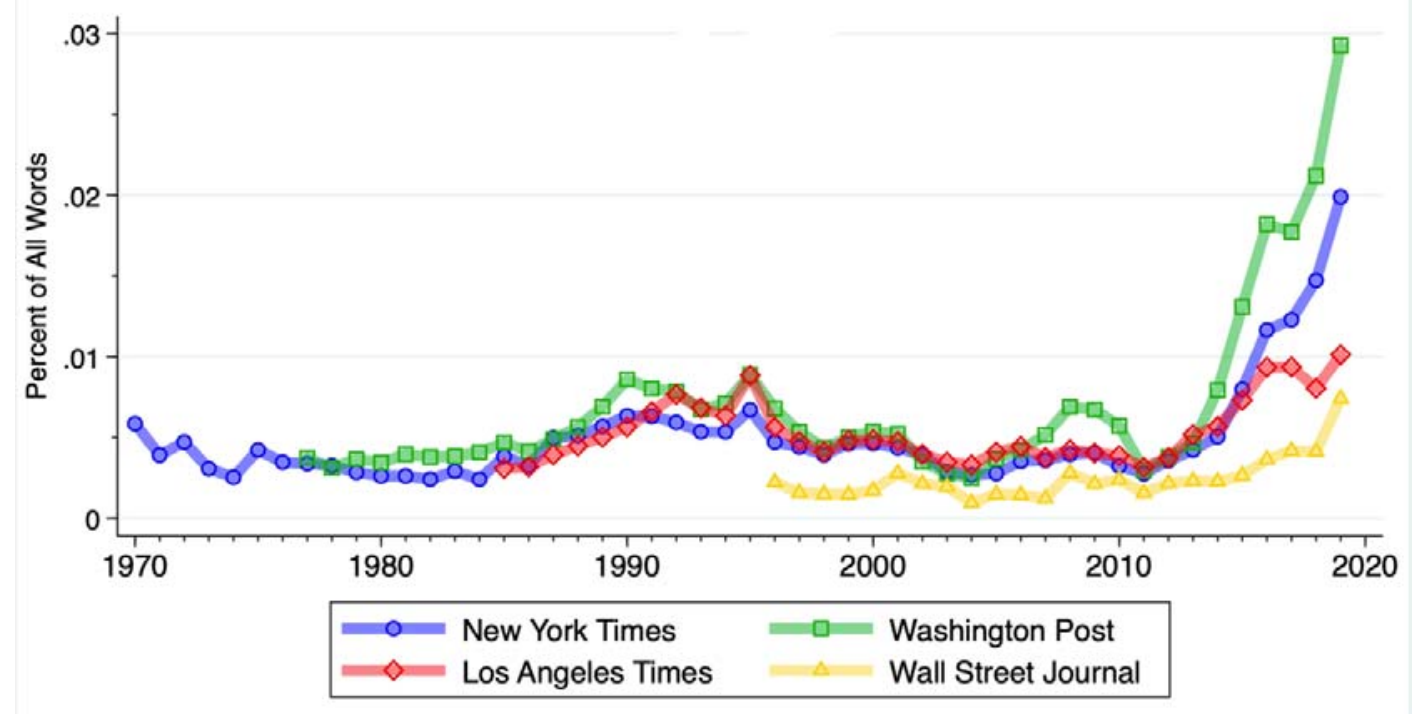

Fig. 2. The use of the words "racist" and "racism" in the four major daily newspapers in the United States Source: Goldberg (2020).

Historically, European universities have always favored controversy, considered a normal form of constitution and transmission of scientific knowledge. The most emblematic case is that of the medieval tradition of disputatio, for which the combat of ideas keeps the scholar and the 
student in a state of vivacity that prevents them from sinking into lethargy. At the time of the Renaissance, disputatio took the form of challenges based on an ethic of intellectual confrontation, where the reputation of scholars was at stake through their argumentative abilities. Rigorous rules were then put in place to organize debates in reference to a true European savoir-vivre of "scholarly dispute" (Pantin, 1997). It would therefore be possible for this historical legacy to remain very present, while avoiding wokist aberration that make any scholarly argument on societal issues difficult, if not impossible. Is this the case? The objective is to answer the question, in other words to know if the woke culture syndrome constitutes a credible threat to researchers, especially researchers in management, knowing that a country like France seems in turn affected by the phenomenon (Joannidès de Lautour, 2021). For this purpose, the research note takes different managerial themes, which have been dealt with in the past in academic contributions, but which could be challenged if wokism spreads.

\section{Methodology}

As indicated, the main research theme is the threats to certain works conducted in management. The methodology is based on the identification of weak signals in the sense of Ansoff (1975), in other words, early warning information of low intensity that may herald major disruptions. These weak signals are identified here in publications conducted outside of management, but which uses certain works in management to conduct a scientific argument on a subject of a societal nature. The approach is therefore close to "critical studies" approaches, but different from them. Critical management research effectively starts from management knowledge and broadens its target to society in order to respond to contemporary issues: "Critical research generally aims to disrupt ongoing social reality for the sake of providing impulses to the liberation from or resistance to what dominates and leads to constraints in human decision making. Typically, critical studies put a particular object of study in a wider cultural, economic and political context" (Alvesson \& Deetz, 2000, p. 1).

In brief, the scientific ambition of critical management research faces the challenge of the complexity of societal problems and facts that a mono-disciplinary approach does not allow to analyze in depth. It is therefore necessary to mobilize multiple disciplines, to make them interact by developing transdisciplinary approaches. In this transdisciplinary perspective, the objective of the research note is to highlight the way in which contributions in social sciences have needed the contributions in management to study the issues at stake, taking the risk of a managerial reading considered as provocative, for example by identifying the implementation and optimization of minority exploitation mechanisms. Several studies have already been carried out to highlight how the advances in woke culture impact the storytelling of companies through "brand activism" (Key et al., 2022; Mirzaei et al., 2022). On the other hand, consulting Google Scholar, very few works in social sciences have used the research conducted in logistics in an explanatory perspective. This research note focuses on.

Logistics is the activity that aims to manage the physical flows of an organization (raw materials, components, sub-assemblies, finished products), by providing resources corresponding to the needs of customers, with a high service quality and in satisfactory conditions of safety and security (Simchi-Levi et al., 2008). Logistics is therefore the network 
of activities and actors that enable the delivery of the right quantity of products at the lowest cost, at the time and place where a demand arises (see Fig. 3). It can refer to a management approach focused on the rationalization of operations related to the movement of products (packaging, conditioning, storage, transport, handling, etc.). Originating from military engineering (Lynn, 1993), logistics was originally considered to be responsible for supplying troops in combat so that they could maintain their operational capabilities over time. However, since the 1960s, business logistics has become a key element of winning strategies for companies (Heskett, 1977). Step by step, a robust knowledge base has been built up, which researchers have used to explore major societal phenomena in a relevant way. This work was conducted in the "pre-wokist" period and the question is whether the woke culture syndrome will prevent its continuation and replication in comparable contexts.

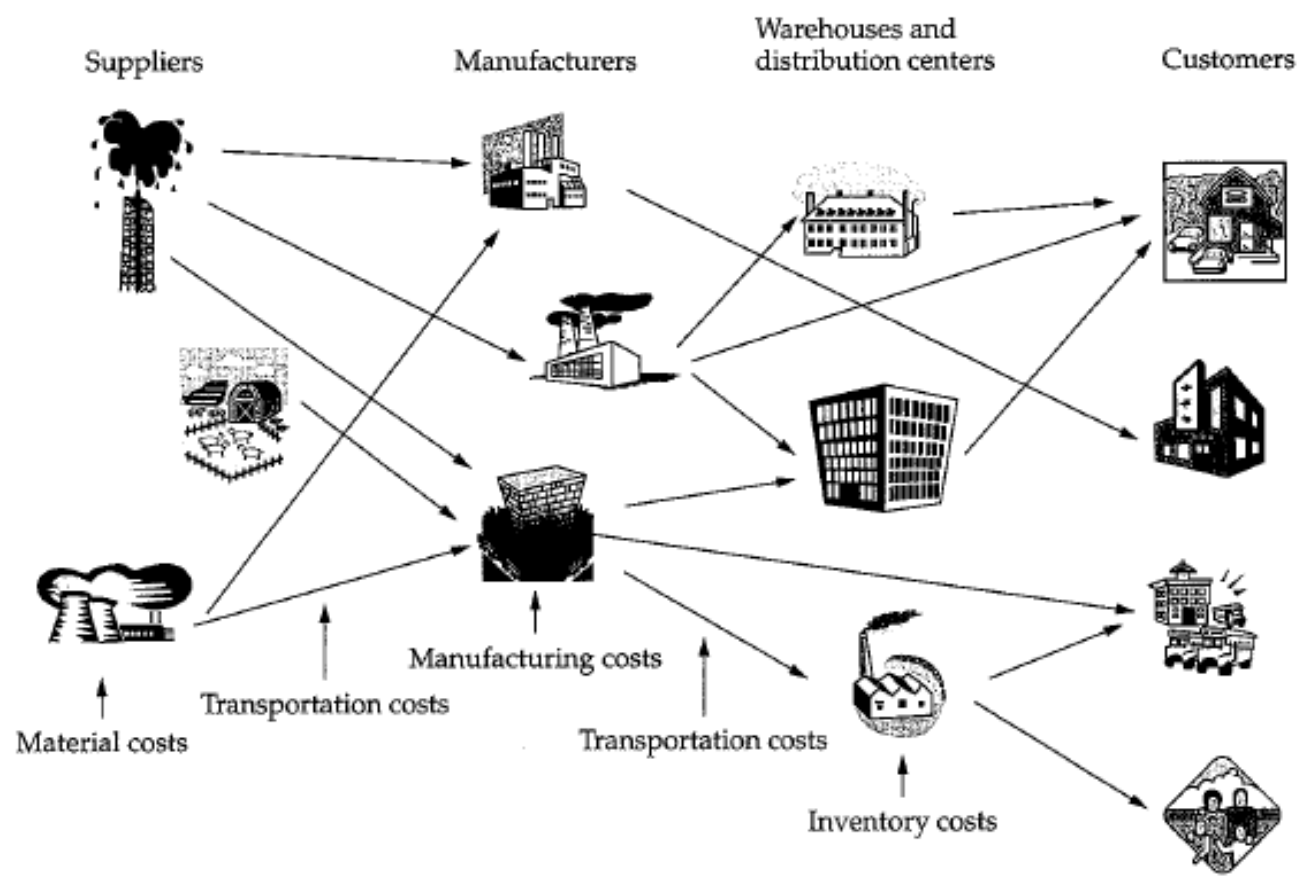

Fig. 3. Logistics: activities and actors

Source: Simchi-Levi et al. (2008).

\section{Results}

The exploration of works using logistics to better understand societal phenomena in a broad sense reveals a relatively small corpus. In most cases, the association of the words "logistics" and "society" leads to papers that deal with corporate social responsibility, the societal efficiency of logistical tools, or the environmental impacts of changing supply chain structures. It is much rarer to see logistics presented as a key element of sociological or historical analyses. Two significant examples are retained in this research note. They have led to interesting results that have been published in academic journals, but whose "sensitive" dimension could trigger an attack of a wokist nature: the logistics as a framework for reading historical phenomena differently (result 1); and the logistics as a framework for better understanding the sex industry (result 2). 


\subsection{Result 1: a new reading of historical phenomena}

The first theme is the role played by the control of global supply chains in the "efficient" monitoring of the Atlantic triangular trade for five centuries. This is a very sensitive subject because it indicates that slavery is an economic system that could only have survived with the help of a remarkable organization of the flow of products and people between three continents. Godbille et al. (2017) have thus been able to point out that the hub-and-spokes model, invented in the 1960s by the creator of FedEx, has its roots in this terrible human traffic. However, contrary to the popular imagery conveyed by the movie and the novel Amistad (Pesci, 1997), for example, many historians have demonstrated, with figures to back them up, that the transport of slaves between the Africa and the Americas did not give rise to any massive excess mortality, the maintenance of slaves in "satisfactory" sanitary conditions being the key to the commercial success of the triangular trade. A wokist approach would undoubtedly speak of an implicit apology for the slavery, and not of the use of proven frameworks to understand the economic fundamentals of the Atlantic triangular trade.

The second theme is an application of the hub-and-spokes model to analyze the Armenian genocide of 1915. Bloxham (2003) speaks of a real "logistical" issue driven by the Young Turks. This death logistics was supervised by civilian and military officials and accompanied by a systematic campaign of mass massacres. Convoys of survivors, exhausted and starving, reach the Syrian desert, where they are parked in concentration camps, where many will not survive. An atlas provides a detailed picture of how the movement of Armenians took place until their deaths (Hewsen, 2001). It shows that a hub-and-spokes model was explicitly set up by the Young Turks through different "relegation zones" within the Ottoman Empire. These are presented as places for grouping families from which deportation routes to the concentration camps were organized, which can be likened here to the radial axes of the hub-and-spokes model. A wokist approach will criticize the researcher in logistics management, totally detached from the horrors of a crime against Humanity, and perhaps accused of congratulating himself/herself on the efficient organization of mass human movements.

\subsection{Result 2: a better understanding of the sex industry}

The first theme concerns an original logistical analysis of the conception and production of low-cost pornographic movies. In a chapter published in France, Paché (2015) suggested a possible application of the modular production model, well known in industrial engineering, to the so-called "X-rated cinema". The idea is simply to film, notably in Asia, in makeshift studios or garages, standard scenes of "sexual prowess", without the actors' visible heads, which could then be used for an almost infinite number of X-rated movies. These standard scenes exist, and they have a name: "inserts". They are mass-produced, just like standard components of a hard disk drive for the manufacture of hundreds of different models of computers. Of course, this organizational model is a modern form of slavery to which women, often young, are subjected. A wokist approach will attack head-on the researcher mobilizing his/her knowledge in logistics management to decipher this form of modular production, which is however a business model widely known in the entertainment industry. 
The second theme concerns the role played by logistics in the management of juvenile prostitution networks in France. Here again, this is a sensitive issue, especially when the researcher knows that this type of prostitution, sometimes involving very young girls, is rampant in certain difficult neighborhoods. However, the work carried out by Lavaud-Legendre \& Plessard (2021) underlines the indispensable presence of logistical resources to organize juvenile prostitution, whether it be hotel rooms or rented apartments, but also means of transport to bring in underage girls and smartphones to manage exchanges between actors. For this, pimps will not hesitate to turn to "service providers" who are responsible for providing the necessary logistical facilities, while ensuring their security. Observers of traditional supply chains immediately draw parallels with the interaction between a shipper and a logistics service provider in the process of subcontracting delivery operations. Can the researcher deny this societal reality, which regularly makes the headlines? On the contrary, the results obtained by the researcher should make it possible to better fight this plague. A wokist approach will hasten to see in this an acceptance by the researcher of male oppression; however, the researcher is content here to describe a modus operandi.

\section{Discussion and conclusion}

Modern societies are regularly crossed by social phenomena that question the functioning of many sectors. With wokism, it is the world of academic research that is now under attack for some of its work, accused of participating in the enslavement of minorities. In the United States, the possibility of open debate on certain sensitive issues is no longer assured, so McMahan et al. (2021) have launched in 2021 the Journal of Controversial Ideas in order to host articles rejected from a wokist perspective. The editorial of the first issue is explicit about the current climate: "Some students have demanded that speakers holding views they consider offensive be prevented from speaking at their university, and that professors holding views the students consider objectionable should be sanctioned or even dismissed" (McMahan et al., 2021, p. 2) For the moment, the management research community does not seem to be suffering from such extremities, even if it recognizes that management practices are influenced by wokism (Middleton \& Turnbull, 2021). But it is not impossible that tomorrow, textbooks by reputable professors will have to be completely rewritten, to erase theories deemed discriminatory, verifying the terrible prophecy of George Orwell in his novel 1984 (Orwell, 1949/2021).

Kim \& Tan (2019) rightly point out that advances in knowledge, especially in the field of strategic management, stem from an ability to mix diverse ideas and theories from different fields, and then confront the resulting frameworks with real-world organizational issues. The four examples given in the present research note confirm this perspective. Whether the researcher is talking about dramatic phenomena that history has known, such as slavery and the Armenian genocide, or the dystopian functioning of the sex industry, such as the production of pornographic movies and juvenile prostitution, the tools resulting from several decades of research in logistics make it possible to highlight key dimensions of phenomena that cannot be ignored. Certainly, these phenomena are morally reprehensible, and there is no question of disputing that. On the other hand, a woke culture that considers that they should no longer be studied, because they adopt a solely "operational" and "neutral" vision of social injustice and 
domination, risks preventing the researcher from bringing out hidden realities. This threat is real, and it would be dramatic to underestimate it.

This research note constitutes a first contribution in a global project to introduce a transdisciplinary vision of social facts. The examples chosen are not random insofar as logistics emerged with the aim of organizing, monitoring and managing the movement of products -and people- in a dual colonial and slave world (Cottias et al., 2010). With the triumph of Taylorism, Fordism and then Toyotism, logistics has given rise to a powerful form of rationality, based on efficiency, speed and reliability in the management of operations. In a way, it is possible to speak of a managerial ideology that represents the world solely as a space of fluid exchanges in the service of capitalism and neoliberalism (Neilson, 2012; Rossiter, 2016; Brennan, 2021), while evacuating the darker sides relating, for example, to the working conditions of the most deprived populations. More broadly, logistics refers to a kind of "modernity" through the implementation of techniques and knowledge allowing the territorial conquest of new spaces (of production and consumption). It would of course be clumsy to write that "everything is logistics". However, it would be just as clumsy to deny the logistical dimensions that the four examples have highlighted.

The main limitation of this scientific exploration is the focusing on four examples, without drawing general conclusions about the different dimensions of wokism and works in social sciences that might be at risk as a research program in relation to each of the dimensions. In particular, wokism revolves around issues of white privilege, systemic racism, colonialism, and male domination (Lopez Bunyasi \& Watts Smith, 2019). From this point of view, it would be interesting to identify in a methodical way the works that address these issues with a managerial perspective, and the questioning of which they have been the object -or not- for the last ten years. In other words, the possible legitimacy of a wokist vision is at stake: systematizing a managerial problematization of different societal issues is probably not desirable, which requires the development of a reflexive capacity towards management knowledge and its practice. It is important to "denaturalize" knowledge, theories and methods in management that tend to be presented as objective. The critical studies movement has been working on this for two decades, as Chanlat (2013) points out, and one of the unsuspected virtues of woke culture could be to participate in this new view of societal realities.

\section{Acknowledgments}

The author thanks two anonymous reviewers of the Journal of Management Research for their constructive comments and suggestions which helped to greatly improve a first draft of the manuscript.

\section{References}

Alvesson, M., \& Deetz, S. (2000). Doing critical management research. London: Sage.

Ansoff, I. (1975). Managing strategic surprise by response to weak signals. California Management Review, 18(2), 21-33. https://doi.org/10.2307/41164635 
Antoniollo, P.-D., \& Camello Lima, C.-R. (2014). Directions for supply chain strategic coordination: discussion and proposals. Journal of Management Research, 6(3), 14-26. https://doi.org/10.5296/jmr.v6i3.5609

Bjorklund, R., \& Green, V. (2012). University trustee board member diversity in America today. Journal of Management Research, 4(3), 222-231. https://doi.org/10.5296/jmr.v4i3.1846

Bloxham, D. (2003). The Armenian genocide of 1915-1916: cumulative radicalization and the development of a destruction policy. Past \& Present, 181, 141-191. https://doi.org/10.1093/past/181.1.141

Brennan, E. (2021). Mapping logistical capitalism. Theory, Culture \& Society, 38(4), 135-146. https://doi.org/10.1177/0263276421990425

Caldera, A. (2018). Woke pedagogy: a framework for teaching and learning. Diversity, Social Justice, \& The Educational Leader, 2(3), 1-11. https://scholarworks.uttyler.edu/dsjel/vol2/iss3/1/

Chanlat, J.-F. (2013). Les études critiques en management: un rappel historique. Communication, 31(1), 3840. https://doi.org/10.4000/communication.3840

Conruyt, C. (2021). Harcelé par des étudiants woke, un professeur d'université témoigne. Le Figaro Etudiant, October 7. https://etudiant.lefigaro.fr/

Cottias, M., Cunin, E., \& de Almeida Mendes, A., Eds. (2010). Les traites et les esclavages: perspectives historiques et contemporaines. Paris: Khartala.

Galvin, B., Randel, A., Collins, B., \& Johnson, R. (2018). Changing the focus of locus (of control), a targeted review of the locus of control literature and agenda for future research. Journal of Organizational Behavior, 39(7), 820-833. https://doi.org/10.1002/job.2275

Garcia Martinez, A. (2016). Chaos monkeys: obscene fortune and random failure in Silicon Valley. New York: Harper.

Godbille, T., Fulconis, F., \& Paché, G. (2017). Organization of transatlantic slave trade: a global supply chain perspective. In Hempel, K., Duedahl, P., \& Poulsen, B. (Eds), Reforms and resources (pp. 73-108). Aalborg: Aalborg University Press.

Goldberg, Z. (2020). How the media led the great racial awakening. Tablet Magazine, August 5. https://www.tabletmag.com/

Guillaume, C., \& Pochic, S. (2019). What would you sacrifice? Access to top management and the work-life balance. Gender, Work \& Organization, 16(1), 14-36. https://doi.org/10.1111/j.1468-0432.2007.00354.x

Hartocollis, A. (2017). A campus argument goes viral. Now the College is under siege. The New York Times, June 16. https://www.nytimes.com/

Heskett, J. (1977). Logistics-Essential to strategy. Harvard Business Review, 55(6), 85-96. https://hbr.org/1977/11/logistics-essential-to-strategy

Hewsen, R. (2001). Armenia: a historical atlas. Chicago (IL), University of Chicago Press. 
Imbler, S. (2021). Ancient-DNA researchers set ethics guidelines for their work. The New York Times, October 20. https://www.nytimes.com/

Joannidès de Lautour, V. (2021). Mouvement woke en France: comment en sommes-nous arrivés là? Les Echos, July 2. https://www.lesechos.fr/idees-debats/

Key, T.-M., Keel, A., Czaplewski, A., \& Olson, E. (2022). Brand activism change agents: strategic storytelling for impact and authenticity. Journal of Strategic Marketing, forthcoming. https://doi.org/10.1080/0965254X.2021.1904435

Kim, K.-H., \& Tan, J. (2019). Implication of paradigm conflicts on theory development in strategic management. Journal of Management Research, 11(1), 79-90. https://doi.org/10.5296/jmr.v11i1.14198

Lavaud-Legendre, B., \& Plessard, C. (2021). L'organisation de l'activité prostitutionnelle des mineures: quand la logistique des plans masque le contrôle. In Cole, E., \& Fougère-Ricaud, M. (Eds.), Protéger les enfants et les adolescents de la prostitution. Volet 1 : comprendre, voir, (se) mobiliser (pp. 67-79). Paris: La Documentation Française.

Lefcourt, H. (1991). Locus of control. In Robinson, J., Shaver, P., \& Wrightsman, L. (Eds.), Measures of personality and social psychological attitudes (pp. 413-499). Cambridge (MA), Academic Press.

ListenFirst (2020). Cancel culture: one topic that is being talked about more on Twitter. August. https://www.listenfirstmedia.com/tag/boycott/

Lopez Bunyasi, T., \& Watts Smith, C. (2019). Stay woke: a people’s guide to making all Black Lives Matter. New York: New York University Press.

Lynn, J. (1993). The history of logistics and supplying war. In Lynn, J. (Ed.), Feeding Mars: logistics in Western warfare from the Middle Ages to the present (pp. 9-27). London: Routledge.

McMahan, J., Minerva, F., \& Singer, P. (2021). Editorial. Journal of Controversial Ideas, 1(1), 1-5. https://doi.org/10.35995/jci01010011

Middleton, K., \& Turnbull, S. (2021). How advertising got "woke": the institutional role of advertising in the emergence of gender progressive market logics and practices. Marketing Theory, 21(4), 561-578. https://doi.org/10.1177/14705931211035163

Mirzaei, A., Wilkie, D., \& Siuki, H. (2022). Woke brand activism authenticity or the lack of it. Journal of Business Research, 139: 1-12. https://doi.org/10.1016/j.jbusres.2021.09.044

Neilson, B. (2012). Five theses on understanding logistics as power. Distinktion: Scandinavian Journal of Social Theory, 13(3), 322-339. https://doi.org/10.1080/1600910X.2012.728533

Orwell, G. (1949/2021). Nineteen eighty-four. London: Penguin. 


\section{Macrothink}

Paché, G. (2015). Universalisme de la pensée logistique: quand le cinéma couple standardisation et différenciation. In Gensse, P., Séverin, E., \& Tournois, N. (Eds.), L'entreprise revisitée: méditations comptables et stratégiques (pp. 153-162). Aix-en-Provence: Presses Universitaires de Provence.

Pantin, I. (1997). La querelle savante dans l'Europe de la Renaissance: éthique et étiquette. Enquête: Anthropologie, Histoire, Sociologie, 5: 71-82. https://doi.org/10.4000/enquete.1093

Pesci, D. (1997). Amistad: the thunder of freedom. New York: Marlowe \& Co.

Rhodes, C. (2022). Woke capitalism: how corporate morality is sabotaging democracy. Bristol: Bristol University Press.

Rom, M., \& Mitchell, K. (2021). Teaching politics in a call-out and cancel culture. Political Science \& Politics, 54(3), 610-614. https://doi.org/10.1017/S10490965521000433

Rossiter, N. (2016). Software, infrastructure, labor: a media theory of logistical nightmares. London: Routledge.

Simchi-Levi, D., Kaminsky, P., \& Simchi-Levi, E. (2008). Designing and managing the supply chain: concepts, strategies, and case studies ( $3^{\text {rd }}$ ed.). New York: McGraw-Hill/Irwin.

Valentin, P. (2021). L'idéologie woke: anatomie du wokisme. Paris: Fondation pour l'Innovation Politique.

Wagener, A. (2021). Le "wokisme" ou l'import des paniques morales. The Conversation, December 8. https://theconversation.com/le-wokisme-ou-limport-des-paniques-morales-172803

Warren, D. (2022). "Woke" corporations and the stigmatization of corporate social initiatives. Business Ethics Quarterly, 32(1), 169-198. https://doi.org/10.1017/beq.2021.48

Wilson, H. (2018). Human reactions to rape culture and queer performativity at urban dog parks in Portland, Oregon. Gender, Place \& Culture: A Journal of Feminist Geography, 27(4), 307-326 [retracted]. https://doi.org/10.1080/0966369X.2018.1475346

\section{Copyrights}

Copyright for this article is retained by the author(s), with first publication rights granted to the journal.

This is an open-access article distributed under the terms and conditions of the Creative Commons Attribution license (http://creativecommons.org/licenses/by/4.0/) 